\section{Commentary: Inversion technique for stentless aortic root - is it wise and necessary?}

\author{
Paul Philipp Heinisch, MD, and Thierry Carrel, MD
}

In the current edition of JCTVS Techniques, Hiremath and Batnaghar ${ }^{1}$ present a technique of stentless aortic root tissue valve implantation using the inversion technique in a single case. The group favors the inversion technique for the implantation of the Medtronic Freestyle prosthesis to enhance visualization and accurate suture placement in a case of infective endocarditis. Hiremath and Batnaghar argue that by inverting the prosthesis, a lower level of implantation into the left ventricular outflow tract may be achieved, especially in situations involving loss of annular tissue, as often seen in infective endocarditis. Using this technique, visualization of the suture line may be improved, especially in case of redo-surgery, small aortic root, and extensive aortic root destruction. The authors conclude that this technique allows precise suture placement, which is of course important to achieve optima alignment of the prosthetic leaflets and to externalize completely any abscess cavity. The technique presupposes the use of the stentless root prosthesis either xenografts or full-root homografts, which additionally provide excellent outflow hemodynamics.

The additional trick of prosthetic inversion seems appealing, but we would like to highlight some limitations of the described technique:

- The authors' recommendations are based on one case only, using a mini-root xenograft prothesis and a very short follow-up without any further morphologic and hemodynamic information on mid-term.

From the Department of Cardiovascular Surgery, University Hospital and University Bern, Bern, Switzerland.

Disclosures: The authors reported no conflicts of interest.

The Journal policy requires editors and reviewers to disclose conflicts of interest and to decline handling or reviewing manuscripts for which they may have a conflict of interest. The editors and reviewers of this article have no conflicts of interest.

Received for publication Nov 2, 2020; revisions received Nov 2, 2020; accepted for publication Nov 13, 2020; available ahead of print Nov 18, 2020.

Address for reprints: Thierry Carrel, MD, Department of Cardiovascular Surgery, Inselspital, University Hospital Bern, Freiburgstrasse 18, CH-3010 Berne, Switzerland (E-mail: thierry.carrel@insel.ch).

JTCVS Techniques 2021;5:6-7

2666-2507

Copyright $(2020$ The Authors. Published by Elsevier Inc. on behalf of The American Association for Thoracic Surgery. This is an open access article under the CC BY-NCND license (http://creativecommons.org/licenses/by-nc-nd/4.0/).

https://doi.org/10.1016/j.xjtc.2020.11.012

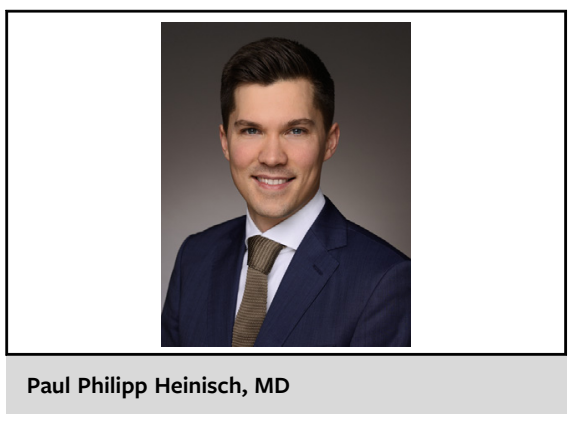

CENTRAL MESSAGE

Inversion of a stentless tissue

valve may facilitate deeper im-

plantation into the left ventricle;

however, careful handling is

required to avoid microinjuries

that could cause early

degeneration.

- The xenograft leaflets of the aortic root prosthesis may be damaged by "inversion" with potential microscopic tears and unnecessary stress on the material to realize inversion but also eversion once the proximal suture line has been performed. This needs to be evaluated during follow-up of the patient's prosthesis.

- Compared with other (non-full root) stentless tissue valves, the Medtronic Freestyle is a rather stiff and thick one; therefore, in a small left ventricular outflow tract, there might be quite a lot of material within the "valve opening area." In such a case, conventional suturing and parachuting the cylindric mini-root may be easier.

- The benefit of the procedures would remain questionable, if the durability of the xenograft valve is affected by the "inversion" technique. When necessary, the annulus can be stabilized by other means, eg, with pericardial patches or strips in case of major annular tissue loss. ${ }^{1}$

- Implanting a stentless aortic root prosthesis at a lower level in the left ventricular outflow tract has not been proven to be advantageous but may cause more conductance disturbances and pacemaker requirement. ${ }^{2-4}$

- Finally, the decision to implant a Freestyle in a 19-yearold patient may be considered as questionable, since this tissue valve will most probably not last for a long time in this age group. With regard to this reality, it seems us very important that the intraoperative "immediate" facilitation of the implantation technique is outweighed against the high probability of reintervention. 
Although the current presentation of the inversion technique cannot provide any significant advantage, it might make the construction of the proximal anastomosis easier in some cases. Nevertheless, the experience with this additional "trick" is very limited.

\section{References}

1. Hiremath N, Batnaghar G. Implantation of stentless aortic root prosthesis using an inversion technique. J Thorac Cardiovasc Surg Tech. 2021;5:1-3.
2. Tomšic A, Schneider AW, Palmen M, van Brakel TJ, Versteegh MIM, Klautz RJM. Extensive infective endocarditis of the aortic root and the aorticmitral continuity: a mitral valve sparing approach. Eur J Cardiothorac Surg. 2017:51:1100-7.

3. Bach DS, Cartier PA, Kon N, Johnson KG, Dumesnil JG, Doty DB, et al. Impact of high transvalvular to subvalvular velocity ratio early after aortic valve replacement with Freestyle stentless aortic bioprosthesis. Semin Thorac Cardiovasc Surg. 2001;13:75-81.

4. Bach DS, Cartier PC, Kon ND, Johnson KG, Deeb GM, Doty DB, et al. Impact of implant technique following freestyle stentless aortic valve replacement. Ann Thorac Surg. 2002;74:1107-13. 